\title{
Are Online and Offline Delinquency Mutually Exclusive? Blurred Boundaries between Cyber Space and the Real-World
}

\author{
Nayoung Ko ${ }^{1}$, Myeonggi Hong ${ }^{2}$, Jeeseon Hwang ${ }^{3}$, Jeonghyeon Chang ${ }^{4}$, and EuiGab Hwang ${ }^{5 *}$ \\ ${ }^{1}$ Department of Criminology, Kyonggi University \\ Yeongtong-gu, ASI KR KS002 SUWON 16227 ROK \\ [e-mail: ninza4966@naver.com] \\ ${ }^{2}$ Department of Criminology, Kyonggi University \\ Yeongtong-gu, ASI KR KS002 SUWON 16227 ROK \\ [e-mail: audrl0406@gmail.com] \\ ${ }^{3}$ Department of Political Science and International Relations, Seoul National University \\ Gwanak, ASI KR KS013 SEOUL 08826 ROK \\ [e-mail: alegrejshwang@gmail.com] \\ ${ }^{4}$ Contents Convergence Software Research Center, Kyonggi University \\ Yeongtong-gu, ASI KR KS002 SUWON 16227 ROK \\ [e-mail: tiger564@nate.com] \\ ${ }^{5}$ Department of Police Administration, Kyonggi University \\ Yeongtong-gu, ASI KR KS002 SUWON 16227 ROK \\ [e-mail: flyhwang@gmail.com] \\ ${ }^{*}$ Corresponding author: EuiGab Hwang
}

Received March 19, 2021; revised June 21, 2021; accepted August 9, 2021;

published August 31, 2021

\begin{abstract}
This study examines the similarities and differences between the causes of juvenile delinquency in online and offline environments and in personal characteristics. The study utilizes data from the '2014 Survey on Juvenile Victimization in Korea'. The population of this survey is students attending middle and high schools across the country. While this paper is based on the Self-Control theory, opportunity factors based on the Routine Activity theory and the Situational Action theory are also applied. Results show that the causes of offline delinquency are low self-control, routine activity and frequent gaming and SNS use. The causes of online delinquency are high self-control, existence of communication with unknown persons and the spectrum of personal information online. The common element of offline and online delinquency was the presence of delinquent peers. These results show that while online and offline delinquency cannot be explained with the same methodology, at the same time they are not mutually exclusive.
\end{abstract}

Keywords: Online and Offline delinquency, Opportunity factors, Routine Activity theory, Self-Control Theory, Situational Action Theory

A preliminary version of this paper appeared in ICONI 2020, December 13-16, Jeju Island, Korea. This research was supported by Basic Science Research Program through the National Research Foundation of Korea(NRF) funded by the Ministry of Education(No. 2020R1A6A1A03040583). 


\section{Introduction}

The evolution of the capabilities of humankind has come hand-in-hand with the rapid development of tools and methods utilized for convenience. The ensuing advent of the age of technology has changed every aspect of peoples' lives. Along with ubiquitous technology, the Internet of things (IoT), artificial intelligence (AI) and smartphones, the Internet has become another common fixture in everyday life. It can be accessed anywhere, and has developed to the extent that it breaks down the boundaries between reality and virtual space. However, technology is a double-edged sword. Traditional crime and delinquency have begun to permeate and proliferate within the boundaries of cyber space and the Internet.

In fact, according to the Cyber bureau of Korea National Police Agency website's 'cybercrime statistics' [20], cybercrime continued to rise from 110,109 cases in 2014, reaching 180,499 cases in 2019. Amongst them, the number of crimes using information and communication networks and illegal content crimes were each both 100,000 higher each year than the number of crimes targeting information and communication networks. Illegal content crimes were particularly prevalent. One explanatory factor is that crimes such as stalking and bullying that used to take place offline have been moved online. Moreover, current issues such as the "Nth Room" incident (production and distribution of sexual imitations), and the proliferation of hidden camera crimes show that even when the actual crime take place offline, cybercrime becomes an extension of the original crime. These examples reflect how blurred the boundaries between cyberspace and real space can become. They also show that the anonymous, non-face-to-face and accessible natures of cyberspace are being utilized in the process of committing crimes.

The fact that cybercrime has gained a reputation for being dangerous and socially threatening can be attributed to the following features. Firstly, the possibility of one perpetrator attacking an unspecified number of individuals could expand the magnitude of victimization to an unpredictable extent. Furthermore, crime committed from remote locations is more difficult to respond to or investigate. To add to this, cybercrimes that anyone with internet access can perpetrate such as cyber verbal violence and cyberbullying are engendering social unrest. Cybercrimes that make use of more sophisticated technologies such as hacking are also becoming threats.

Adolescents represent a particularly avid group of consumers of new technology and researchers estimate that approximately 95\% of adolescents use the Internet every day (Lenhart et al., 2011) [24]. Dependence on electronic gadgets and the internet is thus becoming a serious problem. According to the '2019 Survey on Smartphone Overdependence' by the Korea National Information Society Agency \& Ministry of Science and ICT, one third of teens are addicted to smartphones. Moreover, the risk of adolescents becoming overdependence on smartphones is $30.2 \%$ and getting higher. It is also significantly high compared to other age groups [29]. The results of the survey show that the necessity of studying online delinquency is self-apparent.

For juveniles who immerse themselves in cyber space starting from a relatively young age, cyberspace has become an indispensable part of their everyday lives. Thus establishing solid online ethical standards for juveniles is a particularly urgent issue. However, when the causes of online and offline delinquency are not clear, it is difficult to decide which foundations to base judgements about online ethics on. This study focuses on online juvenile delinquency and analyses differences between the factors of online and offline delinquency. In doing so, study ultimately aims to establish whether factors affecting offline and online delinquency can be mutually exclusive and to use this as a foundation for further studies on the establishment of 
online ethical standards for juveniles.

\section{Theoretical Background}

\subsection{Self-Control Theory}

This study looks to "The Self-Control theory" (Gottfredson and Hirschi, 1990) [10] to explain delinquency. Formulated from a classical viewpoint, this theory focuses on the power to control the manifestation of motives to commit a crime. The Self-Control theory asserts that people have a tendency to pursue desire, and that crime is an easy way to pursue such desires. This theory discusses moderating 'power', which is developed in childhood by parental control, supervision, and parenting attitudes such as discipline. In other words, 'power' is formed by socialization by groups in primary relationships. This concept of power may also be understood as 'self-control', which will be explained further in the next paragraph. The theory thus posits that the difference in levels of self-control is an explanatory factor for why people do not commit crime. [10]

What is the self-control? Within this theory, 'self-control' refers to the ability to resist criminal acts. According to the research, low self-control is formed in childhood, and once established, it does not change throughout one's whole life (Gottfredson \& Hirschi, 1990; Hirschi, 2004) [10] [15].

In this theory, 'low self-control' signifies a lasting personal tendency that ignores long-term costs and desires immediate, easy, and short-term rewards [10]. A major characteristic of people with low self-control is that they often pursue immediate gratification and are impulsive. In contrast, those with high self-control defer gratification relatively to seek longer-term goals (Gottfredson and Hirschi, 1990) [10]. Therefore, those with low self-control have a higher propensity for committing a crime. We have established that low self-control is associated with deviance or crime. However, low self-control does not always mean that a person with this characteristic will commit crime. Low self-control can be counteracted by certain circumstances and therefore does not always lead to crime.

\subsection{Self-Control and Opportunity}

While Gottfredson and Hirschi (1990) [10] did not make direct mention of the impact of opportunity on the relationship between self-control and crime, it can be inferred that they took it into account [12]. More specifically, they made the distinction between crimes and criminality and concluded that the actual occurrence of crimes is shaped by a number of "necessary conditions," including "activity, opportunity, adversaries, victims, [and] goods" (Gottfredson and Hirschi, 1990: 137; LaGrange et. al., 1999) [10] [21].

Current studies have analyzed the effects of opportunity factors on self-control. Hay and Forrest (2008) [12] review again the General Theory of Crime, and find out that opportunity for crime is a key point in the theory. Therefore, this study applies the Routine Activity theory (Cohen and Felson, 1979) [6] and Situational Action Theory (Wikström, 2004) [44] to conceptualize and measure opportunity factors.

\subsection{Routine Activity Theory and Situational Action Theory}

The Routine Activity Theory (Cohen and Felson, 1979) [6] explains crime by combining offender and victim with temporal and spatial environment [5]. In other words, Routine Activity theory views victimization by applying a situational approach (Hindelang et. al., 1978) [13]. This theory specifies three components of the 'crime triangle' which are 1) motivated 
offender, 2) vulnerable target, and 3) the absence of a capable guardian. Usually, the Routine Activity theory is used to study victimization. However, Osgood et. al. (1996) extended the Routine Activity theory perspective to offenders. They argue that the Routine Activity Theory is based on the fact that crime depends on routine activities. The routine activities or situations conducive to deviance are (1) time with peers (2) the absence of authority figures (guardian) (3) unstructured activities (Osgood, Wilson, Malley, Bachman and Johnston, 1996) [31]. Opportunity factors in this theory are unstructured activities with only peers and with no guardian presence.

The Situational Action Theory (SAT) (Wikström, 2004) integrates personal and environmental characteristics to compensate for the defects of the Routine Activity theory, such as the ambiguous concept of the 'motivated offender' [44]. Situational action theory (SAT) aims to explain why crime happens, and more broadly why people follow and break common rules of conduct (Wikström, 2004; 2006; 2010; 2014) [44] [42] [41] [43]. According to the SAT model, action is a result of situation. Namely, when a person (crime propensity) and various environmental settings interact with each other, action arises as a consequence. In the view of SAT, those with high self-control and sense of ethics are less likely to commit crime regardless of exposure to criminal settings (environments). On the other hand, those with low self-control and sense of ethics are more likely to commit crime when they face or are exposed to criminal settings (Wikström, 2009) [45]. Wikström (2009) [45] divided criminal setting into the ethical level peers and low collective-efficacy (Hong, Hong and Lee, 2019) [17].

In accordance with the purposes of this paper, the author adopts the concept of opportunity factors introduced by Hong et. al. (2019), which included unstructured activity without parent surveillance, exposure to delinquent peers and low collective-efficacy [17]. In our paper, we don't use low collective-efficacy, because we cannot measure collective-efficacy in cyber space used by juveniles. Therefore, we adopt two opportunity factors; unstructured activity without parent surveillance and exposure to delinquent peers.

\subsection{Literature Review}

\subsubsection{Self-Control and Delinquency}

Gottfredson and Hirschi (1990) argued that low self-control relate to deviant or criminal behavior [10]. Hirschi and Gottfredson (1993) also contend that, and there are prior researches supports relationship between delinquency or crime and self-control [11].

For instance, Evans et. al. (1997) found out the effects of low self-control on crime and analogous behaviors. In their research, they measured the trait of self-control with 11 Likerttype self-report items. It revealed that self-control was significantly related to crime and imprudent behavior even controlling for social factors. Moreover, this empirical research shows that low self-control has negative effects on the quality of social consequences such as interpersonal relationships with family and friends [7].

There are some studies suggesting that self-control predict imprudent behaviors more precisely than other forms of crime (Baron, Forde and Kay, 2007) [4]. Wood et. al. (1993) conduct a particularly representative study on this topic. Their study mentions that self-control is the strongest predictor for interpersonal delinquency or criminal behavior such as theft, vandalism, legal substance use and especially self-reported delinquency. However, regarding imprudent behaviors, the predictive power of self-control is more accurate and powerful. This signifies that those who are involved in a number of imprudent behaviors can be more engaged in delinquency. (Wood et. al., 1993) [46]. 
However, It can be point out that most studies regarding self-control did not include measures of both crime and analogous behaviors (see Pratt and Cullen, 2000) [32] and few (Wood et. al., 1993; Forde and Kennedy, 1997; LaGrange and Silverman, 1999; Arneklev, Elis, and Medlicott, 2006; Reisig and Pratt, 2011; Meldrum, 2016) [46] [8] [21] [2] [34] [26] have examined the effect of the disaggregated components of self-control on both crime and analogous behaviors. There are some researches criticizing the paradigm of self-control that Gottfredson and Hirschi made. (see, e.g., Arneklev et al.,1998; Geis, 1998; Longshore et al., 1996; Miller and Burack, 1993; Sampson and Laub, 1995; Tittle, 1995) [3] [9] [25] [27] [36] [39]. For example, Andrew and Bonta (1998) indicate that it is not clear whether Gottfredson and Hirschi simply try to package old wine in a new bottle by the concept of "low self-control" which states in their studies. They mention that the series of factors consisting the concept of self-control are empirically best established correlates of criminal conduct [1].

\subsubsection{Self-Control and Opportunity}

The influence of opportunity on the self-control and crime relationship can be assessed because Gottfredson and Hirschi (1990) [10] contend that it may in fact be the interaction between low self-control and opportunity that results in high levels of criminal behavior (see also Grasmick et al., 1993; Longshore, 1998) [11] [24]. Gottfredson and Hirschi (1990) explains that the opportunity factor affecting crime is the result of self-control. [10] Gottfredson and Hirschi (1990) explained that the opportunity factor that explains crime is the result of self-control. Also Hirschi and Gottfredson (1993) mention again in their another paper that concept of self-control can be measured multi-dimensionally by opportunity differences or situational factors [14]. In other words, it is explained that opportunity factors mediate selfcontrol and delinquency, which leads to the assertion that self-control and opportunity are not independent.

However, this paper aims to examine the effects of their interaction by establishing the relations between self-control and opportunity as independent. Opportunity becomes a key factor in many models. LaGrange et. al. (1999) predicts general delinquency, property crime, violent crime, and drug offenses through the general theory of crime, and supports the theory in part to show the relationship between self-control and delinquency which interacts with gender and type of offense [21]. In particular, routine activities theorists (Evans et al., 1997; Forde and Kennedy, 1997; Schreck, Wright and Miller, 2002; Stewart et al., 2004; Hoschsterler and DeLisi, 2005; Pratt, Holtfreter and Reisig, 2010; Reyns, 2013) [7] [8] [37] [38] [16] [33] [35] address the opportunity issue by exploring lifestyle.

Prior research exists that have analyzed the interaction effects of self-control and opportunity factors. Hay and Forrest (2008) analyzed the interaction effects of self-control and opportunity factors. For example, as teenagers spend time with their friends or are not supervised by their parents, Hay and Forrest (2008) analyze and find that the impact of low self-control on delinquency depends in part on the availability of criminal opportunities [12]. Baron et. al. (2007) [4] explores how low self-control, risky lifestyles, and reactions of youth who have run away or been expelled from their homes or loiter impact their involvement in both violent victimization and violent offense, utilizing a sample of 125 homeless male street youth. Results show that particular sub-scales of low self-control affect reaction of street youth to criminal events and the probability of becoming criminals or victims. In addition, Lifestyle and situational dynamics of conflicts influence the tendency to be involved in violence. Longshore (1998) [25], who tested self-control and opportunity as predictors of property and personal crime among drug-users, reported that self-control is a causal factor in criminal behavior, and that the effect is partly contingent on opportunity. In that study, the ability to 
interact between self-control and opportunity is also important. However, its power as a predictive variable is very limited.

Although most studies report that opportunity influences of self-control, Moon and Alarid (2015) [30] show different results. Their findings support the hypothesis that low self-control will predict bullying. However, in their study, when opportunity was involved in the model, the influence of self-control become weak. Thus, opportunity is stronger predictive factors than low self-control.

\subsection{Offline Delinquency and Online Delinquency}

Many prior studies have often used the term "cyber" delinquency to describe crimes committed in cyberspace. However, this study opts to use the word "online" delinquency. First, it is intuitively accepted as a contradictory concept to "offline". Secondly, it is a more familiar word to the public. Thirdly, while "cyber" is an abstract concept that includes mechanical/technical aspects or virtual space, "online" is a conceptualization of the specific use of the Internet or network. We suggest that individuals situated in real life use the Internet or network. In this circumstance, the word "cyber" is only used to refer to as a spatial concept, while the term "online" is used and when talking about behavior such as online delinquency.

Delinquency is an inclusive concept that encompasses juvenile criminal activities as defined in criminal law as well as the narrow concept of juvenile delinquency that is defined by behavior regarded as problematic due to the instigator of behavior being adolescents, not adults. Moreover, online delinquency (some might say cyber delinquency) can be seen as taking place in cyber space [19]. In contrast, hidden delinquency refers to delinquent acts which are harder to trace and the perpetrator is not held responsible for these acts. In criminology, many studies equate delinquency with crime when explaining juvenile crime. However, delinquency cannot be limited to a single conceptualization owing to general views that view delinquency as comprehensive concept including crime, vice, deviance and so on (Yang, 1998; as cited in Lee and Ahn, 2005) [22]. What we call "offline delinquency" is delinquency that takes place in an offline or real world, while "online delinquency" is delinquency which takes place in cyber space when using online (internet or network).

There has been much discussion about the causes of online and offline crimes. From the perspective that regards online crimes and offline crimes as completely independent, the causes of online crimes as compared to offline crimes should be completely different. However, those who see online space as an extension to real space claim that the causes of crime would be similar in both domains.

We have identified studies that view online crime and offline crime independently or as an extension of the real world. Our research assumes that the relationship between delinquency and "low self-control" will be positive, regardless of whether it is online or offline. This is because self-control is based on classical theory and thus seeks the 'generality' of crime. However, this study assumes that the difference of opportunity factors between online and offline environments will cause differences or overlaps in the possibility of committing each type of delinquency.

\subsection{Characteristic of Offline Delinquency and Online Delinquency in Korea (ROK)}

According to the '2019 Crime White Book' published by Institute of Justice in Korea, the rate of juvenile crime, which represents the number of offenders per 100,000 juvenile population, decreased from 1,994.1 in 2009 to 1,446.0 in 2018 [18]. These statistics show that juvenile crime is on the decline. However, these are just reported crimes which do not necessarily measure delinquency. Moreover, the number of offenses did not take into account 
the differences between online and offline crime. According to the Judicial Yearbook (2020) of the Mistry of National Court Administration [28], the number of juvenile probation cases has gradually declined since 2012, with 33.301 cases in 2018. However, the number of cases increased sharply to 26,576 in 2019. Moreover, the number of Special Acts on Information and Communication Networks and violent crime cases has increased. In addition, the age of underage delinquent boys is continuing to drop. This shows that juvenile delinquency is becoming an extremely urgent issue. Delinquency is not always equated with crime, but it actually involves what is called a crime or a highly probable behavior that can lead to a crime. Therefore, more attention must be paid to juvenile delinquency.

The report from the NYPI (National Youth Policy Institute) in 2014 on juvenile cyber bullying shows that the percentage of teenagers who had experiences with both victimization and assault in cyberbullying was high, at $13.1 \%$. Furthermore, the study also shows that school violence was very closely related to cyberbullying. In other words, school violence in offline spaces leads to violence in cyberspace [23]. However, prior studies on juvenile delinquency tend to separate the concepts online and offline delinquency as subjects of analysis.

Using terms such as 'cyber self', these studies tend to assume disparate identities in the real world as opposed to the virtual world or to define these two types of delinquency as independent from each other.

\section{Methodology}

\subsection{Study Sample}

We used data from the '2014 Survey on Juvenile Victimization in Korea', which studies the damage caused by crime against adolescents in Korea. The population of this data is comprised of 7,109 middle school (grade 8) and high school (grades 9, 10 and 11) students across the country attending middle and high schools across the country, and the research method conducted in the study was a multi-level stratified cluster sampling method. The data gathered was analyzed using multi-nominal logistic regression in SPSS.

The dependent variables are the types of delinquency, which are subdivided into four distinct categories: non-delinquency, only offline delinquency, only online delinquency and commit online and offline delinquency (both). The frequency of the non-delinquency group is 4,955 , which is $69 \%$ of the sample. The same results for the offline delinquency group is 1,058 , $14.9 \%$, for the online delinquency group $670,9.4 \%$, and in the both group it is $426,6.0 \%$.

\subsection{Dependent Variables}

To measure delinquency, we used the following questions. All the questions that we selected limited the delinquency period to one year, from the past semester to the present year's summer vacation. First, offline delinquency was measured by:

Drinking (without case drinking with parents or guardian or to perform ancestral rites), smoking, playing truant, running away from home, mugging, assault, threat or intimidation, stealing, pickpocket, group fight, peer harassment, peer swearing the oath, rape, rape attempt, sexual harassment, light molestation, statutory rape.

Online delinquency was measured by:

Illegal downloading, using violent language or swearing online, spreading rumor deliberately online, others' ID or Social Security number unauthorized use, lie about sex or age online, hacking, making personal remarks, slandering online in public, posting email or comments that cause fear or anxiety, transmission or posting up porn, opening others' privacy 
things or personal information, online bullying.

We recoded those questions and recoded offline delinquency into 0 (never) and 1 (performed). Then, we recoded online delinquency into $0=100$ and $1=1,000$ in order to divide the subjects into four groups - no delinquency, only online delinquency, only offline delinquency and both online and offline delinquency. We followed up by computing online delinquency with offline delinquency and came up with the results 100, 101, 1,000 and 1,001. In this case, $100(=0+100)$ is non-delinquency, $101(=1+100)$ is only offline delinquency, $1,000(=0+1,000)$ is only online delinquency and $1,001(=1+1000)$ is both online and offline delinquency. In order to completely separate the 4 groups, we recoded the levels of delinquency into $1(100=1), 2(101=2), 3(1,000=3)$, and $4(1,001=4)$.

\subsection{Independent Variables}

To further analyze and compare the differences between these four types of online and offline delinquency, we examined independent variables concerning self-control factors (Low self-control), routine activity factors and situational action theory (Routine Activity, delinquent peers, communication with unknown persons, exposure of personal information, gaming and SNS use).

Low Self-Control: 1) I do dangerous things for fun. 2) I tend to five up when things get complicated. 3) It is better not to touch me when I'm really angry. 4) I prefer to go outside and move rather than read or think. 5) I prefer to do things with rewards right now rather than things with rewards in the future. 6) I tend to do as I please, even if I cause inconvenience to others.

Routine Activity: 1) I often play outside in the evening. 2) Going around well alone. 3) I often go to arcades, cartoon stores, PC rooms, parks, karaoke, billiards, etc. 4) I often plays outside at night.

Delinquent Peers: Whether or not my close friends have experienced deviant behavior over the past year: 1) Drinking alcohol; 2) Smoking; 3) Absence without leave 4) Beating others severely 5) Stealing other people's money or goods.

Communication with unknown persons: Whether to talk online with someone you've never met personally in real life.

Exposure of Personal Information : 1) Real name 2) Gender 3) Age 4) Job 5) Member (School Name) 6) Residence 7) Interest 8) E-mail Address 9) Mobile Phone 10) Messenger ID 11) Other homepages or SNS Address 12) Photo 13) Love Status 14) Daily life

Gaming: Average gaming time per day over the past year

SNS use : 1) Average daily chat room usage time over the past year 2) Average daily SNS usage time over the past year, such as Kakao Talk, Line, Facebook, Naver band, etc.

\subsection{Control Variables}

This study uses sex, age, income, online victimization and offline victimization as control variables. We decided to control victimization because there are many studies that show large relationship between victimization and offense or delinquency. Because of their robust correlation, we control victimization.

Table 1. Descriptive statistics: Independent, Dependent and Control variables

\begin{tabular}{|c|c|c|c|c|}
\hline $\mathbf{( N = 7 1 0 9 )}$ & Min & Max & Means & Std. Dev \\
\hline \hline Delinquent Group_ Multi-nominal & 1.00 & 4.00 & 1.517 & .893 \\
\hline Low Self-Control & 1.00 & 4.00 & 2.400 & .489 \\
\hline Routine Activities & 1.00 & 4.00 & 2.103 & .692 \\
\hline
\end{tabular}




\begin{tabular}{|c|c|c|c|c|}
\hline Delinquent peers & .00 & 5.00 & .481 & 1.026 \\
\hline Communication with the unknown & .00 & 1.00 & .349 & .477 \\
\hline Exposure of personal information & .00 & 14.00 & 5.270 & 3.492 \\
\hline Gaming & 1.00 & 8.00 & 3.441 & 2.072 \\
\hline SNS use & 1.00 & 8.00 & 3.452 & 1.769 \\
\hline Sex & .00 & 1.00 & .471 & .499 \\
\hline Age & 13.00 & 18.00 & 15.441 & 1.169 \\
\hline Income & 1.00 & 8.00 & 5.696 & 2.025 \\
\hline Online Victimization & .00 & 1.00 & .032 & .175 \\
\hline Offline Victimization & .00 & 1.00 & .088 & .283 \\
\hline
\end{tabular}

\section{Results}

In order to determine whether there were differences in averages between delinquent groups, we conducted a one-way ANOVA test.

Table 2. One-way ANOVA self-control and opportunity factors with four types of online and offline delinquency

\begin{tabular}{|c|c|c|c|c|c|c|c|}
\hline \multicolumn{8}{|c|}{$(N=7109)$} \\
\hline Factors & Group & $\mathbf{N}$ & Mean & $\begin{array}{l}\text { Std. } \\
\text { Dev }\end{array}$ & $\mathbf{F}$ & $\mathbf{P}$ & Scheffe \\
\hline \multirow{4}{*}{ Low Self-Control } & Non-delinquency (a) & 4955 & 2.3633 & .4918 & \multirow{4}{*}{61.22} & \multirow[b]{2}{*}{.000} & \multirow[b]{2}{*}{$a>c$} \\
\hline & $\begin{array}{c}\text { Only Offline } \\
\text { delinquency (b) }\end{array}$ & 1058 & 2.5419 & .4881 & & & \\
\hline & $\begin{array}{c}\text { Only Online } \\
\text { delinquency (c) }\end{array}$ & 670 & 2.3418 & .4229 & & \multirow[t]{2}{*}{$* * *$} & \multirow[t]{2}{*}{$d>b$} \\
\hline & Both (d) & 426 & 2.5724 & .4590 & & & \\
\hline \multirow{4}{*}{ Routine Activities } & Non-delinquency (a) & 4955 & 1.9935 & .6514 & \multirow{4}{*}{93.04} & \multirow[b]{2}{*}{.000} & \multirow[b]{2}{*}{$\mathrm{c}>\mathrm{a}$} \\
\hline & $\begin{array}{c}\text { Only Offline } \\
\text { delinquency (b) }\end{array}$ & 1058 & 2.4853 & .7210 & & & \\
\hline & $\begin{array}{c}\text { Only Online } \\
\text { delinquency (c) }\end{array}$ & 670 & 2.0631 & .6224 & & \multirow[t]{2}{*}{$* * *$} & \multirow[t]{2}{*}{$d>b$} \\
\hline & Both (d) & 426 & 2.4906 & .7143 & & & \\
\hline \multirow{4}{*}{ Delinquent peers } & Non-delinquency (a) & 4955 & .2575 & .7576 & \multirow{4}{*}{417.00} & \multirow[b]{2}{*}{.000} & \multirow{4}{*}{ N/A } \\
\hline & $\begin{array}{c}\text { Only Offline } \\
\text { delinquency (b) }\end{array}$ & 1058 & 1.1957 & 1.4164 & & & \\
\hline & $\begin{array}{c}\text { Only Online } \\
\text { delinquency (c) }\end{array}$ & 670 & .4433 & .9062 & & \multirow[t]{2}{*}{$* * *$} & \\
\hline & Both (d) & 426 & 1.3615 & 1.4078 & & & \\
\hline \multirow{4}{*}{$\begin{array}{l}\text { Communicate with } \\
\text { the unknown }\end{array}$} & Non-delinquency (a) & 4955 & .2878 & .4528 & \multirow{4}{*}{136.15} & \multirow[b]{2}{*}{.000} & \multirow{4}{*}{$d>c$} \\
\hline & $\begin{array}{c}\text { Only Offline } \\
\text { delinquency (b) }\end{array}$ & 1058 & .3781 & .4851 & & & \\
\hline & $\begin{array}{c}\text { Only Online } \\
\text { delinquency (c) }\end{array}$ & 670 & .5791 & .4941 & & \multirow[t]{2}{*}{$* * *$} & \\
\hline & Both (d) & 426 & .6268 & 4842 & & & \\
\hline \multirow{4}{*}{$\begin{array}{l}\text { Exposure of personal } \\
\text { information }\end{array}$} & Non-delinquency (a) & 4955 & 4.8704 & 3.3737 & \multirow{4}{*}{90.81} & \multirow[b]{2}{*}{.000} & \multirow{4}{*}{ N/A } \\
\hline & $\begin{array}{c}\text { Only Offline } \\
\text { delinquency (b) }\end{array}$ & 1058 & 5.7665 & 3.6755 & & & \\
\hline & $\begin{array}{c}\text { Only Online } \\
\text { delinquency (c) }\end{array}$ & 670 & 6.2433 & 3.3726 & & \multirow[t]{2}{*}{$* * *$} & \\
\hline & Both (d) & 426 & 7.1549 & 3.4918 & & & \\
\hline
\end{tabular}




\begin{tabular}{|c|c|c|c|c|c|c|c|}
\hline \multirow{4}{*}{ Gaming } & Non-delinquency (a) & 4955 & 3.2628 & 1.9959 & \multirow{4}{*}{70.45} & \multirow[b]{2}{*}{.000} & \multirow[b]{2}{*}{$\mathrm{a}>\mathrm{c}$} \\
\hline & $\begin{array}{c}\text { Only Offline } \\
\text { delinquency (b) }\end{array}$ & 1058 & 4.1323 & 2.2200 & & & \\
\hline & $\begin{array}{c}\text { Only Online } \\
\text { delinquency (c) }\end{array}$ & 670 & 3.2433 & 2.0087 & & \multirow[t]{2}{*}{$* * *$} & \multirow[t]{2}{*}{$b>d$} \\
\hline & Both (d) & 426 & 4.1127 & 2.1642 & & & \\
\hline \multirow{4}{*}{ SNS use } & Non-delinquency (a) & 4955 & 3.3130 & 1.7293 & \multirow{4}{*}{47.47} & \multirow[b]{2}{*}{.000} & \multirow[b]{2}{*}{$\mathrm{c}>\mathrm{a}$} \\
\hline & $\begin{array}{c}\text { Only Offline } \\
\text { delinquency (b) }\end{array}$ & 1058 & 3.9556 & 1.8942 & & & \\
\hline & $\begin{array}{c}\text { Only Online } \\
\text { delinquency (c) }\end{array}$ & 670 & 3.4172 & 1.6181 & & \multirow[t]{2}{*}{$* * *$} & \multirow[t]{2}{*}{$b>d$} \\
\hline & Both (d) & 426 & 3.8638 & 1.8459 & & & \\
\hline
\end{tabular}

The results for Routine Activity were statistically significant at the 0.01 level with $F=61220$ and $\mathrm{p}=.000$ at the 0.01 significance level. Therefore there were differences between averages. The Scheffe test showed that there were differences in low self-control averages between Nondelinquency and Only online delinquency and also between Both and Only offline delinquency. The average scores were 2.3633 for non-delinquency and 2.3419 for Only online delinquency. The average for non-delinquency was significantly high compared to the average for only online delinquency. The average for Only offline delinquency was 2.5418 while the average for Both was 2.5724. Thus the average for Both was significantly higher.

The results for Routine Activity were statistically significant at the 0.01 level with $\mathrm{F}=93.036$ and $p=.000$. Thus there were meaningful differences among the averages. The Scheffe test showed that there were differences in Routine Activity averages between Non-delinquency and Only online delinquency as well as between Both and Only offline delinquency. The average for Non-delinquency was 1.9935, while the average for Only online delinquency was 2.0631. Thus the average for only online delinquency was significantly high compared to nondelinquency. The average for Only offline delinquency was 2.4853, while the average for Both was 2.4906. Thus the average was significantly higher for Both.

The results for Delinquent peers were statistically significant at the 0.01 level with $F=417.000$ and $p=.000$. Thus there were differences among the averages. However the Scheffe test showed that there were no meaningful differences between the averages of each group.

The results for Routine Activity were statistically significant at the 0.01 level with $\mathrm{F}=136.145$ and $\mathrm{p}=.000$. Thus there were differences among the averages. The Scheffe test showed that there were differences in Communication with the unknown averages between Only online delinquency and Both. The average for Only online delinquency was 0.5791 while the average for Both was 0.6268 . Thus the average was significantly higher for Both.

The results for Exposure of personal information were statistically significant at the 0.01 level with $\mathrm{F}=90.814$ and $\mathrm{p}=.000$. Thus there were differences among the averages. However the Scheffe test showed that there were no meaningful differences between the averages of each group.

The results for Gaming were statistically significant at the 0.01 level with $F=70.446$ and $\mathrm{p}=.000$. Thus there were differences among the averages. The Scheffe test showed that there were differences in Self-Control averages between Non-delinquency and Only online delinquency, as well as between Both and Only offline delinquency. The average for Nondelinquency was 3.2628, while the average for Only online delinquency was 3.2433. The average for Non-delinquency was significantly higher than the average for Only online delinquency. The average for Only offline delinquency was 4.1323 while the average for Both was 4.1127. Thus the average for Only offline delinquency showed a relatively bigger difference. 
The results for SNS use were statistically significant at the 0.01 level with $F=47.468$ and $\mathrm{p}=.000$. Thus there were differences among the averages. The Scheffe test showed that there were differences in Self-Control averages between Non-delinquency and Only online delinquency, as well as between Both and Only offline delinquency. The average for Nondelinquency was 3.3130, while the average for Only online delinquency was 1.61812. The average for Non-delinquency was significantly higher than the average for Only online delinquency. The average for Only offline delinquency was 3.9556, while the average for Both was 3.8638. Thus the average for Only offline delinquency showed a relatively bigger difference.

Table 3. Multi-nominal logistic regression self-control and opportunity factors with four types of online and offline delinquency 1 (Model 1: compared to non-delinquency group)

\begin{tabular}{|c|c|c|c|c|c|c|c|c|}
\hline & \multicolumn{2}{|c|}{ Only Offline Delinquency (A) } & \multicolumn{2}{c|}{ Only Online Delinquency (B) } \\
\hline & B & S.E. & \multicolumn{2}{|c|}{$\operatorname{Exp(B)}$} & B & S.E. & \multicolumn{2}{|c|}{$\operatorname{Exp(B)}$} \\
\hline \hline Low Self-Control & 0.215 & 0.080 & 1.240 & $*$ & -0.262 & 0.096 & 0.770 & $*$ \\
\hline Routine Activity & 0.659 & 0.059 & 1.934 & $* * *$ & 0.113 & 0.070 & 1.120 & \\
\hline Delinquent peers & 1.399 & 0.071 & 4.052 & $* * *$ & 0.475 & 0.099 & 1.608 & $* * *$ \\
\hline Communication with the unknown & 0.122 & 0.080 & 1.130 & & 1.115 & 0.088 & 3.048 & $* * *$ \\
\hline Exposure of personal information & 0.013 & 0.011 & 1.013 & & 0.078 & 0.013 & 1.081 & $* * *$ \\
\hline Gaming & 0.044 & 0.021 & 1.045 & $*$ & 0.023 & 0.025 & 1.024 & \\
\hline SNS use & 0.116 & 0.019 & 1.123 & $* * *$ & -0.054 & 0.022 & 0.947 & $*$ \\
\hline Sex & 0.644 & 0.092 & 1.903 & $* * *$ & -0.553 & 0.106 & 0.575 & $* * *$ \\
\hline Age & 0.114 & 0.033 & 1.121 & $* *$ & 0.040 & 0.037 & 1.041 & \\
\hline Income & 0.011 & 0.019 & 1.011 & & -0.005 & 0.021 & 0.995 & \\
\hline Online Victimization & 0.442 & 0.214 & 1.556 & $*$ & 0.619 & 0.213 & 1.857 & $*$ \\
\hline Offline Victimization & 0.438 & 0.126 & 1.549 & $* *$ & 0.660 & 0.133 & 1.935 & $* * *$ \\
\hline
\end{tabular}

Table 4. Multi-nominal logistic regression self-control and opportunity factors with four types of online and offline delinquency 2 (Model 1: compared to non-delinquency group)

\begin{tabular}{|c|c|c|c|c|}
\hline & \multicolumn{4}{|c|}{ Both (C) } \\
\hline & B & S.E. & \multicolumn{2}{|c|}{$\operatorname{Exp(B)}$} \\
\hline \hline Low Self-Control & 0.295 & 0.120 & 1.344 & $*$ \\
\hline Routine Activity & 0.671 & 0.087 & 1.955 & $* * *$ \\
\hline Delinquent peers & 1.487 & 0.097 & 4.425 & $* * *$ \\
\hline Communication with the unknown & 0.959 & 0.115 & 2.610 & $* * *$ \\
\hline Exposure of personal information & 0.105 & 0.017 & 1.111 & $* * *$ \\
\hline Gaming & 0.067 & 0.030 & 1.070 & $* * *$ \\
\hline SNS use & -0.005 & 0.028 & 0.995 & $*$ \\
\hline Sex & 0.181 & 0.134 & 1.199 & \\
\hline Age & -0.029 & 0.048 & 0.971 & \\
\hline Income & -0.056 & 0.027 & 0.946 & $*$ \\
\hline Online Victimization & 1.348 & 0.208 & 3.849 & $* * *$ \\
\hline Offline Victimization & 1.006 & 0.146 & 2.736 & $* * *$ \\
\hline
\end{tabular}

Table 3 and Table 4 is the result of a multinomial logistic regression analysis, subdividing delinquency into four groups by delinquency type. Model 1 is a result that compares each delinquency group with the non-delinquency group, and Model 2 compares groups that committed only online delinquency with groups that committed only offline delinquency. The model is statistically robust $\left(x^{2}=2052.052, p<0.001\right)$, and accounts for $29.7 \%$ of the total variants of the dependent variables (Nagelkerke $R^{2}=0.297$ ). 
Table 5. Model fit

\begin{tabular}{|c|c|}
\hline Cox and Snell $\boldsymbol{R}^{\mathbf{2}}$ & 0.251 \\
\hline Nagelkerke $\boldsymbol{R}^{\mathbf{2}}$ & 0.297 \\
\hline -2LL & 11112.111 \\
\hline $\boldsymbol{x}^{\mathbf{2}}$ & $2052.025^{* * *}$ \\
\hline
\end{tabular}

More specifically, the analysis results of each model are as follows. First off, A is a comparison between the non-delinquency and offline delinquency groups. Low self-control was shown to have a statistically significant impact, with a one-unit increase in the coefficient increasing the odds of belonging to the offline delinquency group by $24 \%\left(e^{B}=1.240, \mathrm{p}<0.05\right)$. As for the opportunity factors, offline delinquency opportunity factors such as routine activity $\left(e^{B}=1.934, \mathrm{p}<0.001\right)$ and delinquent peers $\left(e^{B}=4.052, \mathrm{p}<0.001\right)$ were statistically significant independent variables. With a one unit increase in routine activity, the odds of belonging to the offline delinquency group were increased by $93.4 \%$, and the numbers of delinquent peers were increased by $305.2 \%$. Communication with unknown persons online, which is an opportunity factor for online delinquency, was not statistically significant. In contrast, games $\left(e^{B}=1.045, \mathrm{p}<0.05\right)$ and SNS use $\left(e^{B}=1.123, \mathrm{p}<0.001\right)$ were statistically significant. This means that with a one-unit increase in gaming time, the odds of belonging to the offline delinquency group would increase by $4.5 \%$, and a one-unit increase in SNS usage time, would increase the odds by $12.3 \%$.

$\mathrm{B}$, which compares non-delinquency and online delinquency groups, showed that lower self-control had a significant impact, and that a one-unit increase in the coefficient, decreased the odds of belonging to the online delinquency group by $23 \%\left(e^{B}=0.770, \mathrm{p}<0.05\right)$. For the offline delinquency opportunity factors, routine activities were statistically insignificant, but delinquent peers $\left(e^{B}=1.608, \mathrm{p}<0.001\right)$ were statistically significant. For delinquent peers, each increase in the number of peers increased the odds of belonging to the online delinquency group by $60.8 \%$. Among the online delinquency opportunity factors, online communication with strangers $\left(e^{B}=3.048, \mathrm{p}<0.001\right)$, exposure of personal information $\left(e^{B}=1.081, \mathrm{p}<0.001\right)$, and SNS use time $\left(e^{B}=0.947, \mathrm{p}<0.05\right)$ were statistically significant in contrast to gaming time, which was not statistically significant. With a one-unit increase in communication with unknown persons and exposure of personal information, the odds of belonging to an online delinquency group increased by $204.8 \%$ and $8.1 \%$ each, while the odds decreased by $5.3 \%$ as the time of using SNS increased by one unit.

$\mathrm{C}$ is a comparison of non-delinquency to both offline and online delinquency. First of all, among the low control $\left(e^{B}=1.344, \mathrm{p}<0.05\right)$ and opportunity factors, all of them were statistically significant, except for SNS use (Routine activity; $e^{B}=1.955, \mathrm{p}<0.001$, delinquent peers; $e^{B}=4.425, \mathrm{p}<0.001$, communication with the unknown online; $e^{B}=2.610, \mathrm{p}<0.001$, exposure of personal information; $e^{B}=1.111, \mathrm{p}<0.001$, gaming; $e^{B}=1.070, \mathrm{p}<0.05$ ). The lower the self-control, the higher possibility of belonging to both types. As online delinquency factors such as communication with strangers online and the exposure of personal information increased by one unit, the odds of belonging to Group C increased by $161 \%$ and $11.1 \%$ each, and the game increased by $4 \%$ with each one-unit increase. 
Table 6. Multi-nominal logistic regression self-control and opportunity factors with online and offline delinquency (Model 2, compared to only offline delinquency group)

\begin{tabular}{|c|c|c|c|c|}
\hline & \multicolumn{4}{|c|}{ Only online delinquency(D) } \\
\hline & B & S.E. & $\operatorname{Exp(B)}$ \\
\hline \hline Low Self-Control & -0.477 & 0.115 & 0.621 & $* * *$ \\
\hline Routine Activity & -0.546 & 0.084 & 0.579 & $* * *$ \\
\hline Delinquent peers & -0.924 & 0.106 & 0.397 & $* * *$ \\
\hline Communication with the unknown & 0.992 & 0.109 & 2.697 & $* * *$ \\
\hline Exposure of personal information & 0.065 & 0.016 & 1.067 & $* * *$ \\
\hline Gaming & -0.020 & 0.030 & 0.980 & \\
\hline SNS use & -0.170 & 0.027 & 0.843 & $* * *$ \\
\hline Sex & -1.197 & 0.129 & 0.302 & $* * *$ \\
\hline Age & -0.074 & 0.046 & 0.928 & \\
\hline Income & -0.015 & 0.026 & 0.985 & \\
\hline Online Victimization & 0.177 & 0.251 & 1.193 & \\
\hline Offline Victimization & 0.223 & 0.159 & 1.249 & \\
\hline
\end{tabular}

Model 2, which compares exclusively offline delinquency groups with exclusively online delinquency groups, produces results that show that lower self-control significantly impacts delinquency $\left(e^{B}=0.621, \mathrm{p}<0.001\right)$. As for the delinquency opportunity factors, none of the factors were statistically significant except for gaming (Routine activity; $e^{B}=0.0579, \mathrm{p}<0.001$, delinquent peers; $e^{B}=0.397, \mathrm{p}<0.001$, communication with the unknown online; $e^{B}=2.697$, $\mathrm{p}<0.001$, exposure of personal information; $e^{B}=1.067, \mathrm{p}<0.001$, time spent on SNS; $e^{B}=0.843$, $\mathrm{p}<0.001)$ had statistically significant effects. Among all of these, only online communication with strangers and exposure of personal information had positive effects. This signifies that the other opportunity factors explain offline delinquency better than online delinquency.

\section{Conclusion}

There are clearly some differences between the causes of offline and online delinquency. First, Low self-control, routine activities and delinquent peers have an effect on both the offline delinquent group and the both groups. However, they do not have an effect on online delinquency. Moreover, Table 2 represents that the online delinquent group has higher selfcontrol than non-delinquent groups.

However, several of our findings show similarities in the factors that engender both online and offline delinquency. For example, SNS and games which are only available online both affect offline delinquency. Moreover, delinquent peers which can be found offline play a part in causing online delinquency. Therefore, online and offline delinquency cannot be classified as completely independent of each other.

Moreover, the results show that the higher the self-control, the more likely to commit online delinquency. These findings contradict previous discussions on the relationship between selfcontrol and delinquency. Therefore, further research that focuses on how opportunity factors such as communication with strangers or exposure of personal information (opportunity factors which only affect online delinquency) affects adolescents is required. 


\section{Discussion}

Must online and offline delinquency be conceptually divided? Some online factors affect offline delinquency. Therefore, the two are not mutually exclusive and must not be seen as completely different types of delinquency.

Does a "cyber self" exist? Our results show that only offline and only online delinquency exist. Thus some adolescents act completely differently in online and offline environments, suggesting that a "cyber self" is plausible.

Is the term "cyber self" accurate? This term implies that one person can have two identities. However, the "self" is a continuous concept, and for adolescents whose daily lives are connected with online spaces it is meaningless to separate the two "selves". Therefore, it is more important to study the effects of cyberspace on personal characteristics rather than focus on the formation of a "cyber self".

These days, education for children is also available online. Therefore, the government should encourage parenting education about how to establish online ethics for children so as to modify their teenage online ethics and in extension, their teenage online behavior. Schools also should provide online ethics education just as much as offline violence education. It is important to make them aware that online society is no different from offline society.

However, online ethical standards for adolescents have not yet been established. Identify is formed not just in one realm but within the interaction of online and offline environments. Therefore, standards for online ethics must be connected to ethics that affect the offline world. The interplay of various online and offline factors in forming a comprehensive ethical standard is a subject which requires further discussion and study.

Data limitation leaves a lot to be desired. The year 2014 is not too long ago, but with the rapid development of the Internet, the latest possible data would be conducive to producing more up-to-date results. Moreover, our research shows that the higher the self-control, the higher the possibility of online delinquency. These findings contradict previous discussions on the relationship between self-control and delinquency. While these findings were discussed briefly, more research on this in the future would strengthen our findings.

\section{Appendix}

\begin{tabular}{|c|c|c|c|c|c|c|c|c|}
\hline & & $\begin{array}{c}\text { Multi-nominal } \\
\text { delinquent }\end{array}$ & (a) & (b) & (c) & (d) & (e) & (f) \\
\hline \multirow{3}{*}{$\begin{array}{l}\text { Low self-control } \\
\text { (a) }\end{array}$} & \multirow{2}{*}{ Pearson $r$} & .094 & \multirow{2}{*}{1} & & & & & \\
\hline & & ** & & & & & & \\
\hline & $\begin{array}{c}\text { Sig } \\
\text { (2-tailed) }\end{array}$ & .000 & & & & & & \\
\hline \multirow{3}{*}{$\begin{array}{l}\text { Routine activities } \\
\text { (b) }\end{array}$} & \multirow{2}{*}{ Pearson $r$} & .192 & .289 & \multirow{2}{*}{1} & & & & \\
\hline & & $* * *$ & $* *$ & & & & & \\
\hline & $\begin{array}{c}\text { Sig } \\
\text { (2-tailed) }\end{array}$ & . 000 & .000 & & & & & \\
\hline \multirow{3}{*}{$\begin{array}{l}\text { Delinquent peers } \\
\text { (c) }\end{array}$} & \multirow{2}{*}{ Pearson $r$} & .281 & .136 & .236 & \multirow{2}{*}{1} & & & \\
\hline & & $* *$ & $* *$ & $* *$ & & & & \\
\hline & $\begin{array}{c}\text { Sig } \\
\text { (2-tailed) }\end{array}$ & .000 & .000 & .000 & & & & \\
\hline
\end{tabular}




\begin{tabular}{|c|c|c|c|c|c|c|c|c|}
\hline \multirow{3}{*}{$\begin{array}{l}\text { Communication } \\
\text { with the } \\
\text { unknown } \\
\text { (d) }\end{array}$} & \multirow{2}{*}{ Pearson $r$} & .229 & .075 & .089 & .107 & \multirow{2}{*}{1} & & \\
\hline & & $* *$ & $* *$ & $* *$ & $* *$ & & & \\
\hline & $\begin{array}{c}\text { Sig } \\
\text { (2-tailed) }\end{array}$ & .000 & .000 & .000 & .000 & & & \\
\hline \multirow{3}{*}{$\begin{array}{l}\text { Exposure of } \\
\text { personal } \\
\text { information } \\
\text { (e) } \\
\end{array}$} & \multirow{2}{*}{ Pearson r } & .191 & .087 & .171 & .159 & .175 & \multirow{2}{*}{1} & \\
\hline & & $* *$ & $* *$ & $* *$ & $* *$ & $* *$ & & \\
\hline & $\begin{array}{c}\text { Sig } \\
\text { (2-tailed) }\end{array}$ & .000 & .000 & .000 & .000 & .000 & & \\
\hline \multirow{3}{*}{$\begin{array}{l}\text { Gaming } \\
\text { (f) }\end{array}$} & \multirow{2}{*}{ Pearson $\mathrm{r}$} & .101 & .133 & .221 & .115 & .152 & -.026 & \multirow{2}{*}{1} \\
\hline & & $* *$ & $* *$ & $* *$ & $* *$ & $* *$ & $*$ & \\
\hline & $\begin{array}{c}\text { Sig } \\
\text { (2-tailed) }\end{array}$ & .000 & .000 & .000 & .000 & .000 & .030 & \\
\hline
\end{tabular}

\begin{tabular}{|c|c|c|c|c|c|c|c|c|}
\hline & & $\begin{array}{c}\text { Multi-nominal } \\
\text { delinquent }\end{array}$ & (a) & (b) & (c) & (d) & (e) & (f) \\
\hline \multirow{3}{*}{$\begin{array}{l}\text { SNS use } \\
\text { (g) }\end{array}$} & \multirow{2}{*}{ Pearson $\mathrm{r}$} & .090 & .154 & .233 & .131 & .119 & .269 & .223 \\
\hline & & $* *$ & $* *$ & $* *$ & $* *$ & $* *$ & $* *$ & $* *$ \\
\hline & $\begin{array}{c}\text { Sig } \\
\text { (2-tailed) }\end{array}$ & .000 & .000 & .000 & .000 & .000 & .000 & .000 \\
\hline \multirow{3}{*}{$\begin{array}{l}\text { Sex } \\
\text { (h) }\end{array}$} & \multirow{2}{*}{ Pearson r } & .031 & .083 & .121 & .124 & .037 & -.145 & .444 \\
\hline & & $* *$ & $* *$ & $* *$ & $* *$ & $* *$ & $* *$ & $* *$ \\
\hline & $\begin{array}{c}\text { Sig } \\
\text { (2-tailed) } \\
\end{array}$ & .009 & .000 & .000 & .000 & .002 & .000 & .000 \\
\hline \multirow{3}{*}{$\begin{array}{l}\text { Age } \\
\text { (i) }\end{array}$} & \multirow{2}{*}{ Pearson $r$} & .031 & \multirow{2}{*}{.022} & .073 & .075 & -.059 & .117 & -.098 \\
\hline & & $* *$ & & $* *$ & $* *$ & $* *$ & $* *$ & $* *$ \\
\hline & $\begin{array}{c}\text { Sig } \\
\text { (2-tailed) }\end{array}$ & .008 & .069 & .000 & .000 & .000 & .000 & .000 \\
\hline
\end{tabular}

\begin{tabular}{|c|c|c|c|c|c|c|c|c|}
\hline & & $\begin{array}{c}\text { Multi-nominal } \\
\text { delinquent }\end{array}$ & (a) & (b) & (c) & (d) & (e) & (f) \\
\hline \multirow{3}{*}{$\begin{array}{l}\text { Income } \\
\text { (j) }\end{array}$} & \multirow{2}{*}{ Pearson $r$} & \multirow{2}{*}{-.005} & \multirow{2}{*}{.004} & .057 & \multirow{2}{*}{.018} & \multirow{2}{*}{-.021} & .064 & -.036 \\
\hline & & & & $* *$ & & & $* *$ & ** \\
\hline & $\begin{array}{c}\text { Sig } \\
\text { (2-tailed) }\end{array}$ & .653 & .710 & .000 & .138 & .074 & .000 & .002 \\
\hline \multirow{3}{*}{$\begin{array}{c}\text { Online } \\
\text { victimization } \\
(\mathrm{k})\end{array}$} & \multirow{2}{*}{ Pearson $r$} & .168 & .053 & .047 & .124 & .118 & .108 & .039 \\
\hline & & $* *$ & $* *$ & $* *$ & $* *$ & $* *$ & $* *$ & $* *$ \\
\hline & $\begin{array}{c}\text { Sig } \\
\text { (2-tailed) }\end{array}$ & .000 & .000 & .000 & .000 & .000 & .000 & .001 \\
\hline \multirow{3}{*}{$\begin{array}{c}\text { Offline } \\
\text { victimization }\end{array}$} & \multirow{2}{*}{ Pearson $\mathrm{r}$} & .173 & .029 & .047 & .161 & .103 & .097 & .039 \\
\hline & & $* *$ & $*$ & $* *$ & $* *$ & $* *$ & $* *$ & $* *$ \\
\hline & $\begin{array}{c}\text { Sig } \\
\text { (2-tailed) }\end{array}$ & .000 & .014 & .000 & .000 & .000 & .000 & .001 \\
\hline
\end{tabular}

\begin{tabular}{|c|c|c|c|c|c|c|c|}
\hline & & $\begin{array}{c}\text { Multi-nominal } \\
\text { delinquent }\end{array}$ & (g) & (h) & (i) & (j) & (k) \\
\hline \multirow{3}{*}{$\begin{array}{l}\text { SNS use } \\
\text { (g) }\end{array}$} & \multirow{2}{*}{ Pearson r } & .090 & \multirow{2}{*}{1} & & & & \\
\hline & & $* *$ & & & & & \\
\hline & $\begin{array}{c}\text { Sig } \\
\text { (2-tailed) }\end{array}$ & .000 & & & & & \\
\hline
\end{tabular}




\begin{tabular}{|c|c|c|c|c|c|c|c|}
\hline \multirow{3}{*}{$\begin{array}{l}\text { Sex } \\
\text { (h) }\end{array}$} & \multirow{2}{*}{ Pearson r } & .031 & -.178 & \multirow{2}{*}{1} & & & \\
\hline & & $* *$ & $* *$ & & & & \\
\hline & $\begin{array}{c}\text { Sig } \\
\text { (2-tailed) }\end{array}$ & .009 & .000 & & & & \\
\hline \multirow{3}{*}{$\begin{array}{l}\text { Age } \\
\text { (i) }\end{array}$} & \multirow{2}{*}{ Pearson $\mathrm{r}$} & .031 & -.052 & -.069 & \multirow{2}{*}{1} & & \\
\hline & & $* *$ & $* *$ & $* *$ & & & \\
\hline & $\begin{array}{c}\text { Sig } \\
\text { (2-tailed) }\end{array}$ & .008 & .000 & .000 & & & \\
\hline \multirow{3}{*}{$\begin{array}{l}\text { Income } \\
\text { (j) }\end{array}$} & \multirow{2}{*}{ Pearson $r$} & \multirow{2}{*}{-.005} & \multirow{2}{*}{-.022} & .071 & \multirow{2}{*}{-.017} & \multirow{2}{*}{1} & \\
\hline & & & & $* *$ & & & \\
\hline & $\begin{array}{c}\text { Sig } \\
\text { (2-tailed) }\end{array}$ & .653 & .58 & .000 & .144 & & \\
\hline \multirow{3}{*}{$\begin{array}{c}\text { Online } \\
\text { victimization } \\
(\mathrm{k})\end{array}$} & \multirow{2}{*}{ Pearson r } & .168 & .087 & -.051 & \multirow{2}{*}{-.018} & \multirow{2}{*}{-.022} & \multirow{2}{*}{1} \\
\hline & & $* *$ & $* *$ & $* *$ & & & \\
\hline & $\begin{array}{c}\text { Sig } \\
\text { (2-tailed) } \\
\end{array}$ & .000 & .000 & .000 & .134 & .066 & \\
\hline \multirow{3}{*}{$\begin{array}{c}\text { Offline } \\
\text { victimization }\end{array}$} & \multirow{2}{*}{ Pearson $\mathrm{r}$} & .173 & .040 & .025 & -.003 & .011 & .138 \\
\hline & & $* *$ & $* *$ & $*$ & & & $* *$ \\
\hline & $\begin{array}{c}\text { Sig } \\
\text { (2-tailed) }\end{array}$ & .000 & .001 & .038 & .807 & .333 & .000 \\
\hline
\end{tabular}

\section{Exp(B) of Model A, B, C and D Graph}

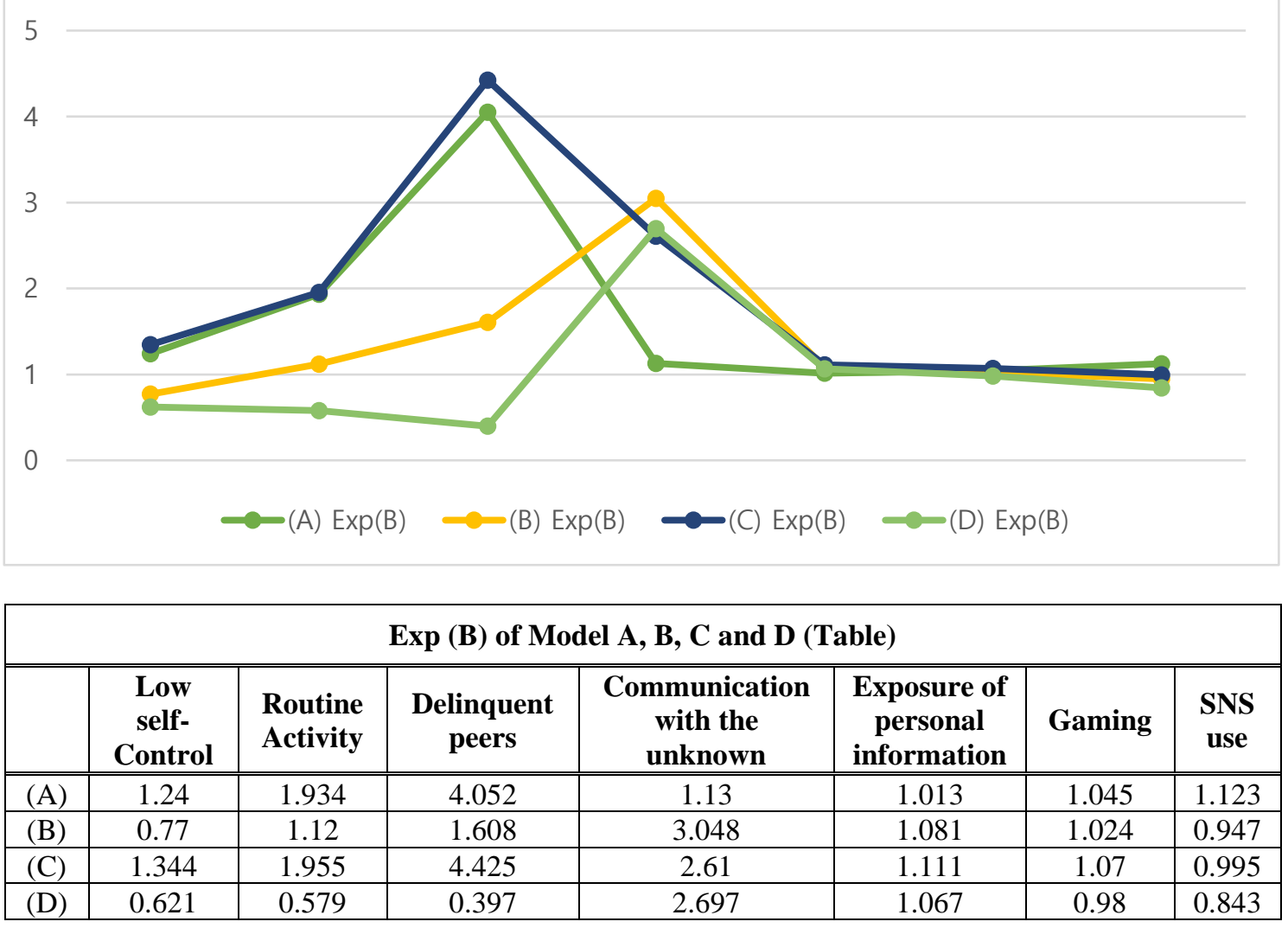




\section{Acknowledgement}

We would like to thank Dr. Kwanghoon Pio Kim, Director of the the Contents Convergence Software Research Institute of Kyonggi University for his helpful support and guidance.

\section{References}

[1] Andrews, D. A., \& Bonta, J., The psychology of criminal conduct, Routledge, 2010.

[2] Arneklev, B. J., Elis, L., \& Medlicott, S., "Testing the General Theory of Crime: Comparing the Effects of "Imprudent Behavior" and an Attitudinal Indicator of "Low Self-Control"," Western Criminology Review, vol.7, no.3, Dec. 2006. Article (CrossRef Link)

[3] Arneklev, B.J., Grasmick, H.G. \& Bursik, R.J., "Evaluating the Dimensionality and Invariance of "Low Self-Control"," Journal of Quantitative Criminology, vol. 15, no. 3, pp. 307-331, Sep, 1999. Article (CrossRef Link)

[4] Baron, S. W., Forde, D. R., \& Kay, F. M., "Self-control, risky lifestyles, and situation: The role of opportunity and context in the general theory," Journal of Criminal Justice, vol. 35, no. 2, pp.119136, March-April. 2007. Article (CrossRef Link)

[5] Britt, C. L., "Self-Control, Group Solidarity, and Crime: An Integrated Control Theory," in Control Theories of Crime and Delinquency, New Jersey, USA : Transaction Publishers, Rutgers, 2003, 161-178

[6] Cohen, L. E., \& Felson, M., "Social change and crime rate trends: A routine activity approach". American Sociological Review, vol. 44, no.4, pp. 588-608, Aug. 1979. Article (CrossRef Link)

[7] Evans, T. D., Cullen, F. T., Burton Jr, V. S., Dunaway, R. G., \& Benson, M. L., "The social consequences of self-control: Testing the general theory of crime,” Wiley. Criminology, vol. 35, no. 3, pp. 475-504, Aug. 1997. Article (CrossRef Link)

[8] Forde, D. R., \& Kennedy, L. W., "Risky lifestyles, routine activities, and the general theory of crime,” Justice Quarterly, vol. 14, no. 2, pp. 265-294, 1997. Article (CrossRef Link)

[9] Geis, G., "On the absence of self-control as the basis for a general theory of crime: A critique," Theoretical Criminology, vol. 4, no. 1, pp. 35-53, Feb. 2000. Article (CrossRef Link)

[10] GOTTFREDSON, Michael R., HIRSCHI, Travis, A general theory of crime, CA, USA: Stanford University Press, 1990.

[11] Grasmick, H. G., Tittle, C. R., Bursik Jr, R. J., \& Arneklev, B. J., "Testing the core empirical implications of Gottfredson and Hirschi's general theory of crime," Journal of research in crime and delinquency, vol. 30, no. 1, pp. 5-29, Feb. 1993. Article (CrossRef Link)

[12] Hay, C., \& Forrest, W., "Self-control theory and the concept of opportunity: The case for a more systematic union," Criminology, vol. 46, no. 4, pp. 1039-1072, Dec. 2008. Article (CrossRef Link)

[13] Hindelang, Michael J., Michael R. Gottfredson, and James Garofalo, Victims of Personal Crime: An Empirical Foundation for a Theory of Personal Victimization, Cambridge, MA: Ballinger. 1978.

[14] Hirschi, T., \& Gottfredson, M., “Commentary: Testing the general theory of crime,” Journal of research in crime and delinquency, vol. 30, no. 1, pp. 47-54, Feb, 1993. Article (CrossRef Link)

[15] Hirschi, T., "Self-control and crime," in Handbook of self-regulation; Research, Theory, and Applications, NY, USA: THE GUILFORD PRESS, pp. 537-552, 2004. [Online]. Available: http://ndl.ethernet.edu.et/bitstream/123456789/28342/1/162.pdf.pdf\#page=556

[16] Hochstetler, A., \& DeLisi, M., "Importation, deprivation, and varieties of serving time: An integrated-lifestyle-exposure model of prison offending," Journal of criminal justice, vol. 33, no. 3, pp. 257-266, May-June, 2005. Article (CrossRef Link)

[17] Hong, M., Hong, S., \& Lee, M., "Self-control and Opportunity as Factors of Juvenile Delinquency: Integration of Individual and Environmental Opportunity Factors," KCI. KOREAN CRIMINOLOGICAL REVIEW, vol. 30, no.4, pp. 203-240, Dec. 2019. Article (CrossRef Link)

[18] Institute of Justice, “Crime White Book 2019,” Institute of Justice Press, Republic of Korea, 2020. [Online]. Available:https://www.ioj.go.kr/homepage/information/DataAction.do?method=view 
[19] Kim. J., Noh. S., “An Empirical Study on the Relationship Between Social Classes and Juvenile Delinquency,” KCI. Korean Journal of Criminology, vol.4, pp. 197-237, Dec. 1989.

[20] Korea Cyber bureau of Republic of Korea, Cybercrime Statistics, Republic of Korea, Rep. 20142018. [Online]. Available: https://www.cyber.go.kr/share/sub3.jsp?mid=030300

[21] LaGrange, T. C., \& Silverman, R. A. "Low self-control and opportunity: Testing the general theory of crime as an explanation for gender differences in delinquency," Criminology, vol. 37, no. 1, pp. 41-72, Feb. 1999. Article (CrossRef Link)

[22] Lee Jung-Sook, Ahn Yoon-Young. "A Study of Use of Computer by Elementary Schoolers and Cyber-Related Delinquency,” KCI. Studies on Korean Youth, vol. 16, no. 1, pp. 225-254, Jun. 2005. Article (CrossRef Link)

[23] Lee, C., Sin, N., \& Ha, E., “A Study on the Situation of Youth Cyberbullying and Measures to Prevent It,” National Youth Policy Institute, Sejong, Republic of Korea, Rep. 14-R07, Dec. 2014. [Online].Available: https://203.254.187.10/dl_image/IMG/01/000000000384/SERVICE/000000000384_01.PDF

[24] Lenhart, A., Madden, M., Smith, A., Purcell, K., Zickuhr, K., \& Rainie, L., “Teens, Kindness and Cruelty on Social Network Sites: How American Teens Navigate the New World of Digital Citizenship,” Pew Internet \& American Life Project, Washington, D.C., USA, Rep. ED537516, Nov, 2011. [Online]. Available: https://files.eric.ed.gov/fulltext/ED537516.pdf

[25] Longshore, D., "Self-control and criminal opportunity: A prospective test of the general theory of crime,” Social problems, vol. 45, no. 1, pp. 102-113. Feb, 1998. Article (CrossRef Link)

[26] Meldrum, R. C., "Low self-control takes flight: The association between indicators of low selfcontrol and imprudent airline passenger behavior," The Social Science Journal, vol.53, no.4, pp.444-454, Dec. 2016. Article (CrossRef Link)

[27] Miller, S. L., \& Burack, C., "A Critique of Gottfredson and Hirschi's General Theory of Crime: Selective (In) Attention to Gender and Power-Positions,” Women \& Criminal Justice, vol. 4, no. 2, pp. 115-134, 1993. Article (CrossRef Link)

[28] Ministry of Justice, “Judicial Yearbook 2019,” Ministry of Justice, Gwacheon, Republic of Korea, 2020. [Online]. Available:http://www.moj.go.kr/bbs/moj/167/526171/artclView.do

[29] Ministry of Science and ICT \& National Information Society Agency, "The survey on smartphone overdependence,” Ministry of Science and ICT \& National Information Society Agency, Sejong \& Daegu, Republic of Korea, Rep. NIA VIII-RSE-C-19067. [Online]. Available: https://www.iapc.or.kr/mediaView.do?idx=28\&article_id=ICCART_0000000113015\&type=A1 \#this

[30] Moon, B., \& Alarid, L. F., “School bullying, low self-control, and opportunity,” Journal of interpersonal violence, vol. 30, no. 5, pp. 839-856, Mar, 2015. Article (CrossRef Link)

[31] Osgood, D. W., Wilson, J. K., O'malley, P. M., Bachman, J. G., \& Johnston, L.D., "Routine activities and individual deviant behavior," American sociological review, vol. 61, no. 4, pp. 635655, Aug, 1996. Article (CrossRef Link)

[32] Pratt, T. C., \& Cullen, F. T., "The empirical status of Gottfredson and Hirschi's general theory of crime: A meta-analysis,” Criminology, vol. 38, no. 3, pp. 931-964, Aug. 2000. Article (CrossRef Link)

[33] Pratt, T. C., Holtfreter, K., \& Reisig, M. D., "Routine online activity and internet fraud targeting: Extending the generality of routine activity theory," Journal of Research in Crime and Delinquency, Vol. 47, no.3, pp. 267-296, Aug, 2010. Article (CrossRef Link)

[34] Reisig, M. D., \& Pratt, T. C., “Low self-control and imprudent behavior revisited,” Deviant Behavior, vol.32, no.7, pp. 589-625, Dec. 2011. Article (CrossRef Link)

[35] Reyns, B. W., "Online routines and identity theft victimization: Further expanding routine activity theory beyond direct-contact offenses," Journal of Research in Crime and Delinquency, vol.50, no.2, pp. 216-238, Nov. 2013. Article (CrossRef Link)

[36] Sampson, R. J., \& Laub, J. H., "Understanding variability in lives through time: Contributions of life-course criminology,” Studies on Crime \& Crime Prevention, vol. 4. no. 2, pp. 143-158, 1995. Article (CrossRef Link) 
[37] Schreck, C. J., Wright, R. A., \& Miller, J. M., "A study of individual and situational antecedents of violent victimization,” Justice Quarterly, vol. 19, no. 1, pp. 159-180, 2002. Article (CrossRef Link)

[38] Stewart, E. A., Elifson, K. W., \& Sterk, C. E., "Integrating the general theory of crime into an explanation of violent victimization among female offenders," Justice Quarterly, vol. 21, no. 1, pp. 159-181, 2004. Article (CrossRef Link)

[39] Tittle, C. R., Control balance: Toward a general theory of deviance, Routledge, 2018.

[40] Wells, L. E., Social control and self-control theories of crime and deviance, Routledge, 2017.

[41] Wikström P.O.H., "Explaining Crime as Moral Actions," in Handbook of Sociology and Social Research, NY, USA: Springer, 2010, pp. 211-239. Article (CrossRef Link)

[42] Wikström, P. O. H., "Individuals, settings, and acts of crime: Situational mechanisms and the explanation of crime," in The explanation of crime: Context, mechanisms and development, New York, USA: CAMBRIGE UNIVERSITY PRESS, 2006, 61-107.

[43] Wikström, P. O. H., "Why crime happens: A situational action theory," in Analytical sociology: Actions and networks, First edition, UK: WILEY, 2014, pp. 74-94. Article (CrossRef Link)

[44] Wikström, P. O. H., "Crime as alternative: Towards a cross-level situational action theory of crime causation," in Beyond empiricism: Institutions and intentions in the study of crime, vol. 13, New Brunswick, USA: Transaction Publishers, 2004, pp. 1-37.

[45] Wikström, Per-Olof H., "Crime Propensity, Criminogenic Exposure and Crime Involvement in Early to Mid Adolescence," Monatsschrift für Kriminologie und Strafrechtsreform, vol. 92, no. 23, pp. 253-266, 2009. Article (CrossRef Link)

[46] Wood, P. B., Pfefferbaum, B., \& Arneklev, B. J., "Risk-taking and self-control: Social psychological correlates of delinquency," Journal of Crime and Justice, vol. 16, no. 1, pp. 111130, 1993. Article (CrossRef Link) 


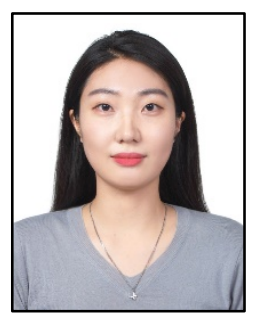

Nayoung Ko received her B.S. degree in both Corrections and Police Administration in 2020 from Kyonggi University in Suwon, South Korea. She is graduate student and major in Criminology at Kyonggi University graduate school. She is a M.A. candidate in Criminology at Kyonggi University, Suwon, South Korea. Her research interests include Criminal Justice, Fear of Crime, Crime Prevention, and Delinquency.

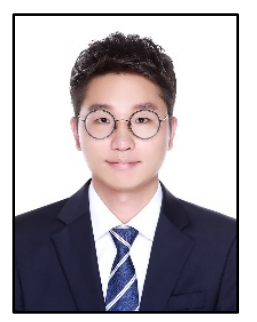

Myeonggi Hong received his B.S. degree in Police Administration from Kyonggi University in Suwon, South Korea. He received M.A. degree in Criminology from Kyonggi University in Suwon, South Korea. He is a Ph.D. candidate in Criminology from Kyonggi University in Suwon, South Korea. He is graduate student in Criminology. His research interests include Criminology theory, delinquency and GIS.

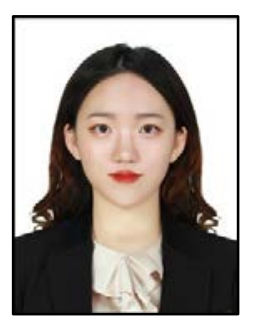

Jeeseon Hwang is an undergraduate student at Seoul National University, Seoul, South Korea. She is majoring in international relations. She has worked as voluntary assistant at the UNWFP Regional Bureau Bangkok and is currently interning at the OECD regulatory policy division. Her fields of interest include international security, human rights, development assistance and public policy.

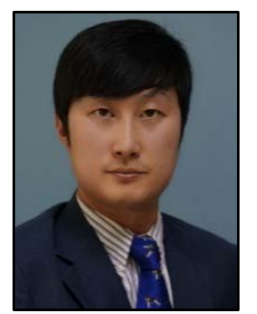

Jeonghyeon Chang received the Ph.D. degree in Police Administration from Kyonggi University, South Korea in 2017. From 2019 to 2020, he also worked as Assistant professor with science of international politics in University of Halla. In 2020, he joined the Contents Convergence Software Research Institute, Kyonggi University, South Korea, where he is currently a Research Professor. His interests include crime prevention through active content, community policing, and data mining.

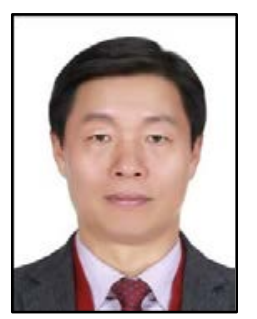

EuiGab Hwang is Professor in the Department of Police Administration at Kyonggi University, South Korea. His Ph.D. in Criminal Justice is from the School of Criminal Justice at Michigan State University. He worked as faculty in the Department of Criminology at Indiana University of Pennsylvania. His recent research appears in Police Quarterly, African and Asian Studies, International Journal of Law, Crime and Justice, Policing: An International Journal of Police Strategies \& Management, Youth Violence and Juvenile Justice, and Journal of Criminal Justice. 